\title{
Growth performance, carcass traits and physical properties of chicken meat as affected by genotype and production system
}

\author{
J. Batkowska ${ }^{1}$, A. Brodacki ${ }^{1}$, G. Ziębaa ${ }^{1}$, J. O. Horbańczuk ${ }^{2}$, and M. Lukaszewicz ${ }^{2}$ \\ ${ }^{1}$ The University of Life Sciences in Lublin, Department of Biological Basis of Animal Production, \\ Lublin, Poland \\ ${ }^{2}$ Institute of Genetics and Animal Breeding Polish Academy of Sciences, Jastrzębiec, Magdalenka, Poland \\ Correspondence to: J. Batkowska (justyna.batkowska@up.lublin.pl)
}

Received: 16 July 2014 - Revised: 19 May 2015 - Accepted: 6 July 2015 - Published: 13 August 2015

\begin{abstract}
The results of this study constitute a part of a project aiming at developing a cross-breed suitable for an extensive rearing system, utilising local biodiversity. Hybrids from mating a commercial broiler's male component (C) with Green-legged Partridgenous (GP) or Sussex (Sx) hens were compared with Cobb broilers. The study included 720 chickens of 3 genetic groups. Up to the third week of age, all birds were fed with balanced mixtures recommended for broiler chickens. From the fourth week, the mixture was weekly reduced by $10 \%$ for the birds kept extensively (E). The deducted part was replaced with wheat bran, and from the seventh week with wheat. E groups had access to runs and received green fodder. Birds were slaughtered in 12th week of life. Carcass yield, giblets and proportion of carcass elements were estimated along with meat traits. The body weight at the 6th, 9th, 12th week of rearing and dissection results indicated a good suitability of Cobb chickens for an extensive rearing system. Hybrids were characterised by a considerably smaller proportion of breast muscle and slightly bigger of thighs and drumsticks, compared with Cobb, which could result from their greater motor activity. Results obtained by $\mathrm{C} \times \mathrm{Sx}$ and $\mathrm{C} \times \mathrm{GP}$ chickens, such as final body weight, proportions of abdominal fat and carcass elements, and appropriate value of meat traits, point at the usefulness of these hybrids as a meat-type chicken under extensive housing conditions. Darker colour of chicken meat, derived from $\mathrm{C}$ cocks and Sx or GP hens crossbred, can constitute an indicator for their carcasses' identification on the market.
\end{abstract}

\section{Introduction}

Chicken's meat obtained through organic or free-range systems is considered to be more valuable in terms of quality traits than meat from birds raised conventionally (Dou et al., 2009; Sundrum, 2001). As factors affecting meat quality, in addition to genotype, Castellini et al. (2008) mention nutrition, age at slaughter and motor activity. Local breeds are suggested to be used for organic farming due to their lower sensitivity to changing environmental conditions and adverse effects from weather (Fanatico et al., 2005, 2006; Rizzi et al., 2007). However, there is an opinion that, under extensive conditions, birds are not able to exploit fully their genetic potential, and their growth is limited by deficient nutrition (Gondwe and Wollny, 2005).
Managing broilers extensively only from the fourth week of birds' age allows for adverse effects of environmental conditions to be reduced on very young bird body systems and introduces the possibility of different feeding for chickens of various sexes. The aim of this study was to evaluate the effectiveness of farming and technological characteristics of meat derived from crossbred cocks of various innate growth rate and depending on the rearing system.

\section{Material and methods}

Male chickens obtained by mating Cornish cocks, which are used as male component for commercial broiler chicken production, with Green-legged Partridgenous (GP) or Sussex (Sx) hens (slow growing) were compared with Cobb broil- 
Table 1. Experimental design.

\begin{tabular}{|c|c|c|c|c|c|c|c|c|c|c|c|}
\hline \multirow[b]{3}{*}{$\hat{0}$} & \multirow{3}{*}{$\begin{array}{l}\text { Cross } \\
\uparrow\end{array}$} & \multicolumn{10}{|c|}{ Rearing system (RS) } \\
\hline & & \multicolumn{5}{|c|}{ Intensive (I) } & \multicolumn{5}{|c|}{ Extensive (E) } \\
\hline & & $\begin{array}{c}\text { No. of } \\
\text { replicates }\end{array}$ & & $\begin{array}{l}\text { No. of } \\
\text { birds }\end{array}$ & & Total & $\begin{array}{c}\text { No. of } \\
\text { replicates }\end{array}$ & & $\begin{array}{l}\text { No. of } \\
\text { birds }\end{array}$ & & Total \\
\hline \multicolumn{2}{|c|}{ Cobb } & 6 & $x$ & 20 & $=$ & 120 & 6 & $x$ & 20 & $=$ & 120 \\
\hline \multicolumn{2}{|c|}{$\mathrm{C} \times \mathrm{Sx}$} & 6 & $x$ & 20 & $=$ & 120 & 6 & $x$ & 20 & $=$ & 120 \\
\hline \multicolumn{2}{|c|}{$\mathrm{C} \times \mathrm{GP}$} & 6 & $x$ & 20 & $=$ & 120 & 6 & $\times$ & 20 & $=$ & 120 \\
\hline \multicolumn{2}{|c|}{ Total } & & & & & 360 & & & & & 360 \\
\hline
\end{tabular}

C - Cornish; GP - Green-legged Partridgenous; Sx - Sussex

ers (fast growing). In total, the study included 720 chickens of 3 genetic groups divided into 6 replications of 20 birds each in 2 rearing systems. The experimental design is shown in Table 1.

The three genetic bird groups, up to the third week of age, were reared under standard intensive conditions and fed with fodder recommended for broiler chickens. Afterwards, the proper experiment started. From week 4, as shown in Table 2, in the extensive feeding group, balanced mixture (grower) was weekly reduced by $10 \%$. The deducted part was replaced by wheat bran and from week 7 also by crushed wheat. Additionally, chickens kept under extensive conditions from the fourth week of age were given access to open runs and received approximately $50 \mathrm{~g}$ of green fodder per day consisting of alfalfa, grass and nettles. Laboratory analyses of the feed were performed weekly. The nutritional value of feed in each week of the experiment is summarised in Table 3 .

Of each replicated group, two chickens were slaughtered after 12 weeks of life. Carcass yield, percentage proportion of giblets and abdominal fat pad in birds' body weight, and percentage proportion of carcass elements were estimated following simplified dissection of carcasses (Hahn and Spindler, 2002). The evaluation of meat quality included $\mathrm{pH}$ measurement $(15,60 \mathrm{~min}$, and $24 \mathrm{~h}$ after slaughter) with the use of a CP-251 pH meter (PN-ISO 2917:2001), waterholding capacity (WHC) following the method of Grau and Hamm (1953), natural drip loss (Lundstrom and Malmfors, 1985 ) and thermal drip loss. One and $24 \mathrm{~h}$ after slaughter, the electrolytic conductance was measured using a MT- 03 conductivity meter. Physical parameters of meat colour $\left(L^{*}, a^{*}\right.$, $\left.b^{*}\right)$ were evaluated by means of reflectance with the use of a Minolta CR-200 colorimeter (CIE, 1978). For the determination of meat tenderness, a Warner-Bratzler shear machine was used.

The data were analysed with the use of the statistical package SPSS 20.0PL (IBM, 2011). The normality of data was verified using the Kolmogorov-Smirnov test. Then a twoway analysis of variance with Duncan's post hoc test was carried out. The statistical model incorporated all the anal- ysed factors, such as birds' genotype (G) and rearing system (RS), and interactions between these factors were compiled.

\section{Results and discussion}

\subsection{Growth rate and carcass traits}

Higher motor activity and definitely better utilisation of runs and vegetation growing on them by birds from the Greenlegged Partridgenous and Sussex crosses compared to heavy Cobb birds are additional observations made during the research. Similar observations were made by Castellini et al. (2002). Birds of slower growth spend more time on the move than broiler-type chickens. At the same time, those authors, as well as Mikulski at al. (2011), pointed to significantly greater mortality of fast-growing birds; this fact confirms their poorer adaptability to extensive rearing conditions.

Differentiation of chicken body weight due to their genotype was observed in all feeding periods of the experiment (Table 4). The rearing system caused differences only in the Cobb chickens. In week 12, body weight of Sx hybrids constituted $61 \%$ of the Cobb's body weight, while that of GP hybrids constituted $39 \%$; Cobb chickens fed extensively were almost $15 \%$ heavier than birds of the intensive group. Similarly, differentiation caused by rearing system was observed in chickens at each of the age classes. These differences changed in time and amounted to $12.3,4.3$ and $3.9 \%$ respectively from the 4 th to 6 th, 7 th to 9 th, and 10th to 12 th rearing weeks, and $21.4 \%$ over the whole trial. Interaction between the studied effects proved insignificant only in the final stage of production. It should be noted that body weight at the 6th, 9th, 12th week of rearing and body weight gains indicated a good suitability of Cobb chickens for an extensive rearing system.

The greatest carcass yield (about $75 \%$ ) was from Cobb chickens (Table 5). Smaller values, about 5.6 and $7.2 \%$, were noticed in $\mathrm{C} \times \mathrm{Sx}$ and $\mathrm{C} \times \mathrm{GP}$ birds respectively. Differences due to rearing system were not statistically significant. However, hybrids, created in carrying out research, were charac- 
Table 2. Feeding regimen across feeding systems and age (percentage proportion of meals).

\begin{tabular}{|c|c|c|c|c|c|}
\hline \multirow[t]{2}{*}{ Time (weeks) } & \multicolumn{5}{|c|}{ Rearing system } \\
\hline & \multicolumn{3}{|c|}{ Extensive (E) } & \multicolumn{2}{|c|}{ Intensive (I) } \\
\hline \multirow[t]{2}{*}{$0-3$} & & $\begin{array}{c}\text { Starter } \\
100\end{array}$ & & & $\begin{array}{c}\text { Starter } \\
100\end{array}$ \\
\hline & Grower & Wheat bran & Crushed wheat & Grower & Crushed wheat \\
\hline 4 & 90 & 10 & & 100 & \\
\hline 5 & 80 & 20 & & 100 & \\
\hline 6 & 70 & 30 & & 100 & \\
\hline 7 & 60 & 30 & 10 & 100 & \\
\hline 8 & 50 & 30 & 20 & 100 & \\
\hline 9 & 40 & 30 & 30 & 100 & \\
\hline 10 & 30 & 40 & 30 & 80 & 20 \\
\hline 11 & 20 & 40 & 40 & 80 & 20 \\
\hline 12 & 10 & 40 & 50 & 80 & 20 \\
\hline
\end{tabular}

Table 3. Nutritive values of feeds used in the experiment, depending on the system of rearing.

\begin{tabular}{|c|c|c|c|c|c|c|}
\hline \multirow[t]{2}{*}{ Age (weeks) } & \multirow[t]{2}{*}{ RS } & \multicolumn{5}{|c|}{ Ingredient $\left[\mathrm{g} 1000 \mathrm{~g}^{-1}\right]$} \\
\hline & & $\mathrm{ME}\left[\mathrm{MJ} 1000 \mathrm{~g}^{-1}\right]$ & Crude protein & Crude fibre & Crude fat & Crude ash \\
\hline \multirow{2}{*}{4} & $\mathrm{E}$ & 11.50 & 203.2 & 35.8 & 40.9 & 47.9 \\
\hline & I & 12.00 & 208.0 & 23.8 & 39.6 & 48.2 \\
\hline \multirow{2}{*}{5} & $\mathrm{E}$ & 11.00 & 193.7 & 40.9 & 42.1 & 47.6 \\
\hline & I & 12.00 & 208.0 & 23.8 & 39.6 & 48.2 \\
\hline \multirow{2}{*}{6} & $\mathrm{E}$ & 10.50 & 183.6 & 46.1 & 43.4 & 47.2 \\
\hline & $\mathrm{I}$ & 12.00 & 208.0 & 23.8 & 39.6 & 48.2 \\
\hline \multirow{2}{*}{7} & $\mathrm{E}$ & 10.59 & 181.4 & 45.4 & 41.3 & 43.9 \\
\hline & I & 12.00 & 208.0 & 23.8 & 39.6 & 48.2 \\
\hline \multirow{2}{*}{8} & $\mathrm{E}$ & 10.68 & 169.3 & 44.8 & 39.1 & 40.6 \\
\hline & I & 12.00 & 208.0 & 23.8 & 39.6 & 48.2 \\
\hline \multirow{2}{*}{9} & $\mathrm{E}$ & 10.77 & 157.1 & 44.1 & 37.0 & 37.3 \\
\hline & I & 12.00 & 208.0 & 23.8 & 39.6 & 48.2 \\
\hline \multirow{2}{*}{10} & $\mathrm{E}$ & 10.27 & 152.3 & 49.2 & 38.3 & 37.0 \\
\hline & I & 11.00 & 183.7 & 40.9 & 42.1 & 47.6 \\
\hline \multirow{2}{*}{11} & $\mathrm{E}$ & 7.28 & 122.9 & 43.8 & 32.5 & 30.7 \\
\hline & I & 11.00 & 183.7 & 40.9 & 42.1 & 47.6 \\
\hline \multirow{2}{*}{12} & $\mathrm{E}$ & 7.87 & 110.7 & 43.1 & 30.4 & 27.4 \\
\hline & I & 11.00 & 183.7 & 40.9 & 42.1 & 47.6 \\
\hline
\end{tabular}

E - extensive system; I - intensive system

terised by a considerably smaller proportion of breast muscle and bigger proportion of trunk in relation to Cobb chickens. Proportions of thighs, drumsticks and wings in carcasses were similar in all genetic groups, and just slightly bigger in newly created hybrids, which could result from their greater motor activity. The influence of feeding and management system on analysed traits was not stated.
The gizzard was considerably bigger in extensively fed birds. This could be the result of a larger amount of fibre in their diet with the wheat bran, crushed wheat and green fodder. Additionally, the proportion of gizzard did not depend on birds' genotype. Gizzards of both of the new hybrids constituted significantly bigger body weight proportion than in the Cobb E group, which may be due to consider- 
Table 4. Body weight gains of birds in particular feeding periods.

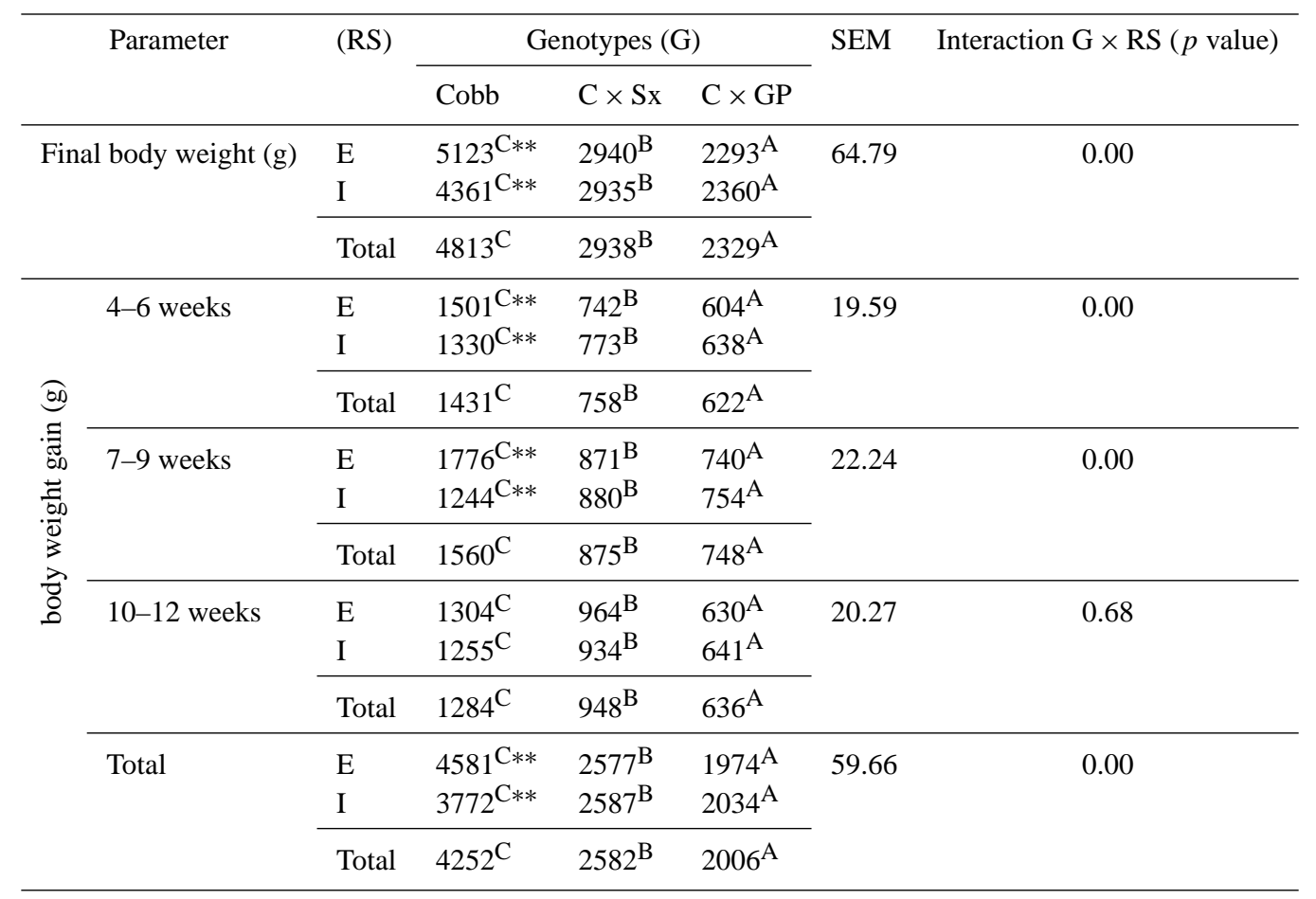

E - extensive system; I - intensive system; ${ }^{\mathrm{A}, \mathrm{B}, \mathrm{C}}$ - differences between means for genotypes significant at $p \leq 0.01 ;{ }^{\text {a,b,c }}-$ differences between means for genotypes significant at $p \leq 0.05$; ** - differences between means for rearing systems significant at $p \leq 0.01$; $^{*}-$ differences between means for rearing systems significant at $p \leq 0.05$

ably bigger body weight of Cobb birds than the other groups. The amount of abdominal fat pad, which can be used as a marker of fat content in the whole carcass, was relatively small (0.30-1.14\%). In the Cobb birds and in $\mathrm{C} \times \mathrm{Sx}$ hybrids in E groups, significantly smaller abdominal fat pads were found compared to groups kept under intensive conditions. The difference in fat amount between $\mathrm{C} \times \mathrm{Sx}$ hybrids and Cobb birds was also statistically significant. GP hybrids were characterised by almost 2 times smaller proportion of this element than heavy broilers. Except for abdominal pad, the interaction between genotype and rearing environment was not statistically significant.

Sogut et al. (2011) obtained bigger body weight under extensive system conditions in birds fed ad libitum in relation to birds given limited levels of energy and protein in their feed. In the paper of Mikulski et al. (2011) the interaction between phenotype (slow- and fast-growing chicken) and rearing system (intensive and organic) was not confirmed in the determination of productive traits such as body weight and feed conversion ratio. Percentage proportion of particular elements in carcasses was influenced mainly by genotype. Also, in research by Berri et al. (2005), the proportion of breast and leg muscles in carcasses remained under significant influence of genotype. This factor also affected $\mathrm{pH}$ value and natural drip loss; the highest and the lowest values of these traits, respectively, were found in the meat of chickens selected for improved growth rate. The present results confirmed the observations of Fanatico et al. (2008), who did not prove the influence of rearing system upon dissection analysis. Slowand fast-growing birds had similar carcass yield regardless of rearing systems. However, those authors stated an effect of a feeding mixture containing reduced amounts of nutrients on slaughter traits. In addition, the reaction observed in slowgrowing birds was more unequivocal than in conventional broilers. Bizeray et al. (2002) evaluated production effects of birds stimulated to greater motor activity by dispersing whole wheat grains on the pen floor. In the group given this additional feed, the conversion ratio was smallest, though body weight was biggest compared to other groups.

\subsection{Meat traits}

Differences between quality traits' means of the breast and thigh muscles in chicken groups and rearing systems are shown in Tables 6 and 7. From analysis of meat colour parameters, the influence of the combination of both experimental factors was not noted. The lightness of breast muscle was homogeneous, whereas meat from newly created hybrids was more red $\left(a^{*}\right)$ and yellow $\left(b^{*}\right)$ in relation to the Cobb broilers. In the thigh muscle, considerably darker colour characterised the meat from the slow-growing birds and it was more saturated with red than meat in birds from 
Table 5. The results of birds' dissection analysis.

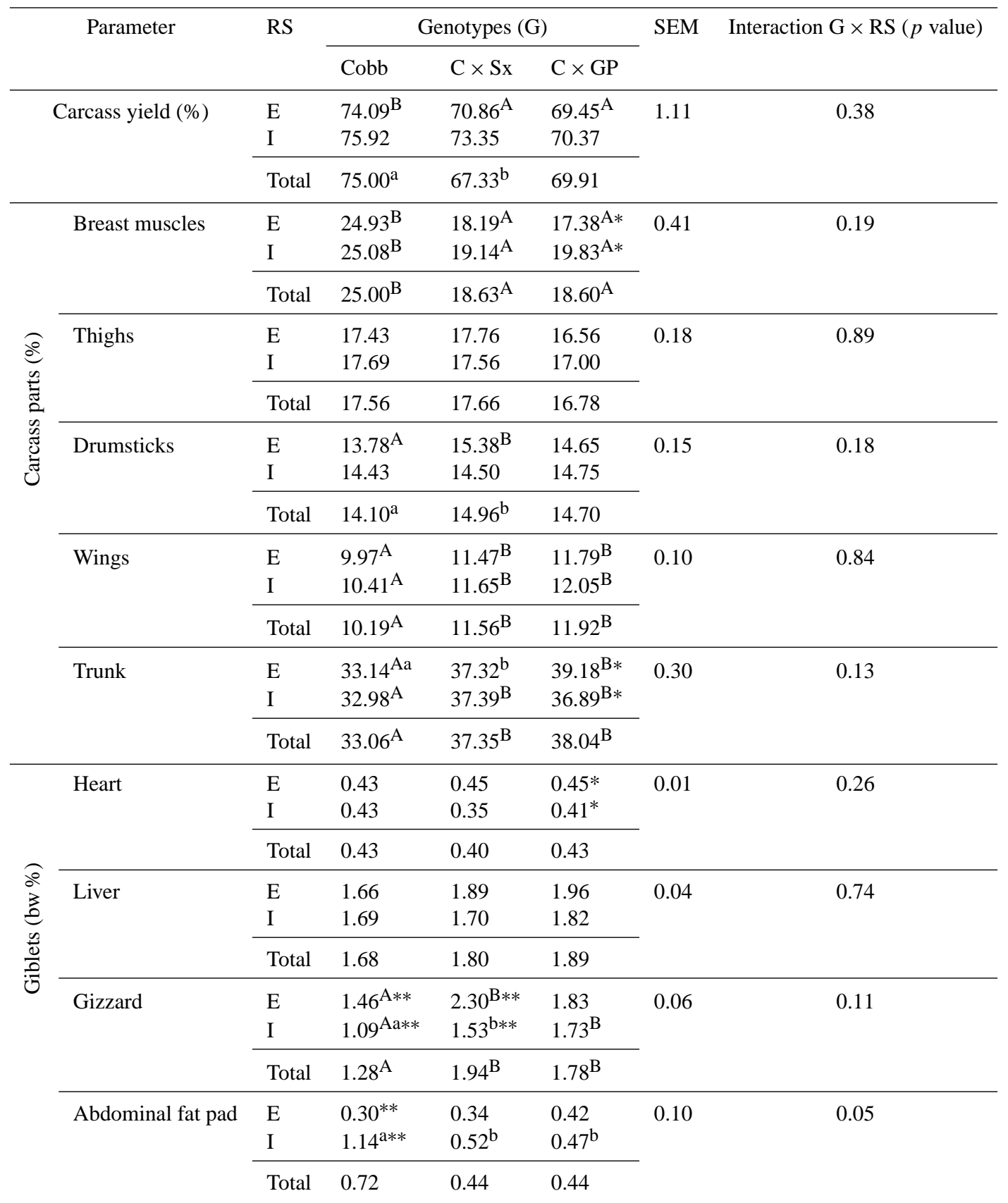

E- extensive system; I - intensive system; bw - body weight, A,B,C - differences between means for genotypes significant at $P \leq 0.01$; ${ }^{\text {a,b,c }}$ differences between means for genotypes significant at $P \leq 0.05$; ** - differences between means for rearing systems significant at $P \leq 0.01$; * - differences between means for rearing systems significant at $P \leq 0.05$.

the broiler group. There was no impact of rearing system on meat colour formation. Also, Fanatico et al. (2007) did not state the changes in carcass colour of broilers which were given access to an outdoor area.

Electrolytic conductance in breast muscle 1 and $24 \mathrm{~h}$ subsequent to slaughter was higher in newly created hybrid groups than in fast-growing birds. Differentiation of conduc- tance caused by rearing system was only noted $24 \mathrm{~h}$ after slaughter. The $\mathrm{pH}$ values of the breast muscle in all groups of birds initially decreased during the first $45 \mathrm{~min}$ after slaughter, and then increased within $24 \mathrm{~h}$. This trend was also observed when measuring $\mathrm{pH}$ in the thigh muscles of chickens from all genetic groups. This may indicate a proper course of post mortem glycolysis in muscles (Berri, 2000). Santé et 
Table 6. Technological traits of meat (breast muscle).

\begin{tabular}{|c|c|c|c|c|c|c|}
\hline \multirow[t]{2}{*}{ Parameter } & \multirow[t]{2}{*}{$\mathrm{RS}$} & \multicolumn{3}{|c|}{ Genotypes (G) } & \multirow[t]{2}{*}{ SEM } & \multirow[t]{2}{*}{ Interaction $\mathrm{G} \times \mathrm{RS}$ ( $p$ value) } \\
\hline & & Cobb & $\mathrm{C} \times \mathrm{Sx}$ & $\mathrm{C} \times \mathrm{GP}$ & & \\
\hline \multirow[t]{3}{*}{$L^{*}$} & $\mathrm{E}$ & $56.76^{\mathrm{b}}$ & $54.11^{\mathrm{a}}$ & 55.14 & 0.33 & 0.95 \\
\hline & I & 56.02 & 53.76 & 54.37 & & \\
\hline & Total & $56.39^{\mathrm{Bb}}$ & $53.95^{\mathrm{A}}$ & $54.75^{\mathrm{b}}$ & & \\
\hline \multirow[t]{3}{*}{$a^{*}$} & $\mathrm{E}$ & $11.86^{\mathrm{A}}$ & $15.45^{\mathrm{B}}$ & $16.07^{\mathrm{B}}$ & 0.28 & 0.94 \\
\hline & $\mathrm{I}$ & $13.04^{\mathrm{A}}$ & $16.42^{\mathrm{B}}$ & $17.39^{\mathrm{B}}$ & & \\
\hline & Total & $12.45^{\mathrm{A}}$ & $15.91^{\mathrm{B}}$ & $16.73^{\mathrm{B}}$ & & \\
\hline \multirow[t]{3}{*}{$b^{*}$} & $\mathrm{E}$ & $2.88^{\mathrm{A}}$ & $3.02^{\mathrm{A} *}$ & $5.10^{\mathrm{B}}$ & 0.21 & 0.65 \\
\hline & I & $2.61^{\mathrm{a}}$ & $1.89^{\mathrm{a} *}$ & $4.87^{\mathrm{b}}$ & & \\
\hline & Total & $2.74^{\mathrm{A}}$ & $2.49^{\mathrm{A}}$ & $4.98^{\mathrm{B}}$ & & \\
\hline \multirow[t]{3}{*}{ Conductivity (1 h S) } & $\mathrm{E}$ & $5.54^{\mathrm{Aa}}$ & $11.80^{\mathrm{b}}$ & $12.94^{\mathrm{B}}$ & 0.82 & 0.68 \\
\hline & I & $5.87^{\mathrm{A}}$ & 9.31 & $12.98^{\mathrm{B}}$ & & \\
\hline & Total & $5.73^{\mathrm{A}}$ & $10.56^{\mathrm{B}}$ & $12.95^{\mathrm{B}}$ & & \\
\hline \multirow[t]{3}{*}{ Conductivity (24 h S) } & $\mathrm{E}$ & 13.24 & $15.46^{*}$ & 14.17 & 0.49 & 0.11 \\
\hline & $\mathrm{I}$ & $11.13^{\mathrm{A}}$ & $17.14^{\mathrm{B} *}$ & $15.30^{\mathrm{B}}$ & & \\
\hline & Total & $12.06^{\mathrm{Aa}}$ & $16.30^{\mathrm{B}}$ & $14.52^{b}$ & & \\
\hline \multirow[t]{3}{*}{$(15 \min )$} & $\mathrm{E}$ & $6.18^{\mathrm{B}}$ & $5.74^{\mathrm{A}}$ & $5.63^{\mathrm{A}}$ & 0.07 & 0.64 \\
\hline & I & $6.16^{\mathrm{B}}$ & $5.62^{\mathrm{A}}$ & $5.72^{\mathrm{A}}$ & & \\
\hline & Total & $6.17^{\mathrm{B}}$ & $5.68^{\mathrm{A}}$ & $5.66^{\mathrm{A}}$ & & \\
\hline \multirow[t]{3}{*}{$(60 \mathrm{~min})$} & $\mathrm{E}$ & 5.71 & 5.69 & 5.68 & 0.02 & 0.58 \\
\hline & I & 5.75 & 5.64 & 5.64 & & \\
\hline & Total & 5.74 & 5.67 & 5.67 & & \\
\hline \multirow[t]{3}{*}{$(24 \mathrm{~h})$} & $\mathrm{E}$ & 5.92 & 5.86 & 5.81 & 0.02 & 0.94 \\
\hline & I & 5.86 & 5.78 & 5.71 & & \\
\hline & Total & $5.89^{\mathrm{b}}$ & 5.82 & $5.78^{\mathrm{a}}$ & & \\
\hline \multirow[t]{3}{*}{ WHC $\left(\mathrm{cm}^{2}\right)$} & $\mathrm{E}$ & 6.77 & 8.24 & 8.10 & 0.27 & 0.63 \\
\hline & I & $6.70^{\mathrm{a}}$ & $8.15^{\mathrm{b}}$ & 9.07 & & \\
\hline & Total & $6.74^{\mathrm{Aa}}$ & $8.20^{\mathrm{b}}$ & $8.58^{\mathrm{B}}$ & & \\
\hline \multirow[t]{3}{*}{ Drip loss (\%) } & $\mathrm{E}$ & $3.20^{\mathrm{a}}$ & 3.24 & $5.41^{\mathrm{b}}$ & 0.34 & 0.70 \\
\hline & I & $2.14^{\mathrm{A}}$ & $3.23^{\mathrm{a}}$ & $5.56^{\mathrm{Bb}}$ & & \\
\hline & Total & $2.63^{\mathrm{A}}$ & $3.24^{\mathrm{A}}$ & $5.48^{\mathrm{B}}$ & & \\
\hline \multirow[t]{3}{*}{ Thermal loss (\%) } & $\mathrm{E}$ & 18.16 & 14.68 & 17.74 & 0.68 & 0.99 \\
\hline & $\mathrm{I}$ & $17.57^{\mathrm{b}}$ & $13.92^{\mathrm{a}}$ & 16.92 & & \\
\hline & Total & $17.83^{b}$ & $14.30^{\mathrm{a}}$ & 17.49 & & \\
\hline \multirow[t]{3}{*}{ Shear force $\left(\mathrm{kg} \mathrm{cm}^{-2}\right)$} & $\mathrm{E}$ & 2.29 & $2.22^{\mathrm{a}}$ & $2.47^{\mathrm{b}}$ & 0.08 & 0.09 \\
\hline & I & 2.70 & 2.51 & 2.73 & & \\
\hline & Total & $2.52^{\mathrm{A}}$ & $2.34^{\mathrm{A}}$ & $2.59^{\mathrm{B}}$ & & \\
\hline
\end{tabular}

E - extensive system; I - intensive system; A,B,C - differences between means for genotypes significant at $P \leq 0.01$; ${ }^{\text {a,b,c }}-$ differences between means for genotypes significant at $P \leq 0.05$; * - differences between means for rearing systems significant at $P \leq 0.05$ 
Table 7. Technological traits of meat (thigh muscle).

\begin{tabular}{|c|c|c|c|c|c|c|}
\hline \multirow[t]{2}{*}{ Parameter } & \multirow[t]{2}{*}{$\mathrm{RS}$} & \multicolumn{3}{|c|}{ Genotypes (G) } & \multirow[t]{2}{*}{ SEM } & \multirow[t]{2}{*}{ Interaction $\mathrm{G} \times \mathrm{RS}$ ( $p$ value) } \\
\hline & & Cobb & $\mathrm{C} \times \mathrm{Sx}$ & $\mathrm{C} \times \mathrm{GP}$ & & \\
\hline \multirow[t]{3}{*}{$L^{*}$} & $\mathrm{E}$ & $51.37^{\mathrm{B}}$ & $45.61^{A *}$ & $45.86^{\mathrm{A}}$ & 0.57 & 0.40 \\
\hline & I & $52.30^{\mathrm{Bb}}$ & $48.94^{\mathrm{a} *}$ & $47.02^{\mathrm{A}}$ & & \\
\hline & Total & $51.83^{\mathrm{B}}$ & $47.18^{\mathrm{A}}$ & $46.44^{\mathrm{A}}$ & & \\
\hline \multirow[t]{3}{*}{$a^{*}$} & $\mathrm{E}$ & $17.24^{\mathrm{A}}$ & $20.23^{\mathrm{B}}$ & $19.48^{\mathrm{B}}$ & 0.28 & 0.88 \\
\hline & I & $16.87^{\mathrm{Aa}}$ & $20.28^{\mathrm{B}}$ & $19.68^{\mathrm{b}}$ & & \\
\hline & Total & $17.06^{\mathrm{A}}$ & $20.25^{\mathrm{B}}$ & $19.58^{\mathrm{B}}$ & & \\
\hline \multirow[t]{3}{*}{$b^{*}$} & $\mathrm{E}$ & 2.90 & 3.01 & 3.13 & 0.19 & 0.89 \\
\hline & I & 3.16 & 3.13 & 3.02 & & \\
\hline & Total & 3.03 & 3.06 & 3.08 & & \\
\hline \multirow[t]{3}{*}{ Conductivity $(1 \mathrm{~h} \mathrm{~S})$} & $\mathrm{E}$ & 6.59 & 5.26 & 5.86 & 0.28 & 0.81 \\
\hline & I & 6.80 & 4.60 & 5.53 & & \\
\hline & Total & $6.71^{\mathrm{b}}$ & $4.93^{\mathrm{a}}$ & 5.75 & & \\
\hline \multirow[t]{3}{*}{ Conductivity (24 h S) } & $\mathrm{E}$ & 10.10 & 7.73 & 10.21 & 0.40 & 0.45 \\
\hline & $\mathrm{I}$ & 10.42 & 8.13 & 8.13 & & \\
\hline & Total & $10.28^{\mathrm{b}}$ & $7.93^{\mathrm{a}}$ & 9.57 & & \\
\hline \multirow[t]{3}{*}{ (15 min) } & $\mathrm{E}$ & 5.97 & 6.08 & 6.08 & 0.03 & 0.68 \\
\hline & I & 6.00 & 6.07 & 5.99 & & \\
\hline & Total & 5.99 & 6.08 & 6.05 & & \\
\hline \multirow[t]{3}{*}{$(60 \mathrm{~min})$} & $\mathrm{E}$ & $5.68^{a}$ & $5.96^{\mathrm{b}}$ & $5.94^{b}$ & 0.04 & 0.07 \\
\hline & $\mathrm{I}$ & 5.87 & 5.88 & 5.81 & & \\
\hline & Total & $5.79^{\mathrm{a}}$ & $5.92^{\mathrm{b}}$ & 5.90 & & \\
\hline \multirow[t]{3}{*}{$\mathrm{pH}_{3}$} & $\mathrm{E}$ & 6.04 & 6.11 & 6.04 & 0.03 & 0.51 \\
\hline & I & 6.04 & 5.94 & 5.92 & & \\
\hline & Total & 6.04 & 6.03 & 6.01 & & \\
\hline \multirow[t]{3}{*}{ WHC $\left(\mathrm{cm}^{2}\right)$} & $\mathrm{E}$ & 8.22 & 8.41 & 8.79 & 0.24 & 0.45 \\
\hline & $\mathrm{I}$ & 7.51 & 9.05 & 8.26 & & \\
\hline & Total & 7.84 & 8.75 & 8.53 & & \\
\hline \multirow[t]{3}{*}{ Drip loss (\%) } & $\mathrm{E}$ & 3.15 & 2.50 & 2.42 & 0.22 & 0.32 \\
\hline & I & 1.92 & 2.63 & 2.83 & & \\
\hline & Total & 2.49 & 2.57 & 2.62 & & \\
\hline \multirow[t]{3}{*}{ Thermal loss (\%) } & $\mathrm{E}$ & 22.20 & 21.54 & 23.80 & 0.91 & 0.79 \\
\hline & I & 24.22 & 21.29 & 24.20 & & \\
\hline & Total & 23.34 & 21.42 & 23.93 & & \\
\hline \multirow[t]{3}{*}{ Shear force $\left(\mathrm{kg} \mathrm{cm}^{-2}\right)$} & $\mathrm{E}$ & $2.25^{* *}$ & 2.68 & 3.04 & 0.11 & 0.08 \\
\hline & I & $2.48^{\mathrm{A} * *}$ & $3.01^{\mathrm{a}}$ & $3.27^{\mathrm{Bb}}$ & & \\
\hline & Total & 2.38 & 2.82 & 3.15 & & \\
\hline
\end{tabular}

E - extensive system; I - intensive system; A, B,C - differences between means for genotypes significant at $P \leq 0.01 ;{ }^{\text {a,b,c }}-$ differences between means for genotypes significant at $P \leq 0.05 ;{ }^{* *}$ - differences between means for rearing systems significant at $P \leq 0.01 ;^{*}-$ differences between means for rearing systems significant at $P \leq 0.05$ 
al. (1996) proved that the post mortem $\mathrm{pH}$ drop in muscles is greater in fast-growing hybrids than in slow-growing birds at the same age. In the current study, the $\mathrm{pH}$ value of breast muscle measured $15 \mathrm{~min}$ after slaughter was significantly smaller in both types of slow-growing hybrids than in commercial broiler-type chickens. In the thigh muscle, slightly greater conductance $24 \mathrm{~h}$ after slaughter and a smaller $\mathrm{pH}$ value $1 \mathrm{~h}$ after in the Cobb birds than in the Sx hybrids were stated.

Meat properties in terms of water-holding capacity showed significant individual variability (Tables 6 and 7); however, there was no effect of the $\mathrm{G} \times \mathrm{RS}$ interaction. The impact of rearing system was not found in water-holding capacity, nor in natural and thermal drip loss. In breast muscle, significantly lower water-holding capacity values were recorded in the Cobb chickens than in slow-growing birds. Similar relations between groups concerned the natural drip loss of meat. Nonetheless, the smallest loss during thermal processing was recorded in $\mathrm{C} \times \mathrm{Sx}$ birds. In the thigh muscle, none of the described parameters showed differences caused by chickens' genotype.

Greater tenderness, measured by the force required to cut through the muscle fibres, was recorded in the breast muscles compared to thigh muscles in all types of hybrids. In the Cobb chickens, breast muscles in birds from the extensive system and thigh muscles in birds from the intensive system were also more tender. In both muscles, lower tenderness was confirmed in $\mathrm{C} \times \mathrm{GP}$ hybrids compared to other genotypes. The smallest shear force to cut was required in muscles of the Cobb broilers. This difference could be explained by their lower motor activity limited by rapid weight gain.

Colour, taste and texture of meat are considered to be the main traits differentiating meat from birds kept in systems of varying intensity. However, Souza et al. (2011) indicated a lack of studies evaluating meat quality indicators in slowgrowing birds dedicated to rearing systems of varying degrees of extensiveness. Birds intended for an extensive management system were characterised by considerably different meat colour than conventional broilers. There was no effect of genotype on water loss from meat during thermal processing.

Połtowicz and Doktor (2011) reported statistically insignificant impact of rearing conditions on physico-chemical characteristics in breast muscles of birds, with exception of $\mathrm{pH}$ measured at $24 \mathrm{~h}$ after slaughter, which was slightly greater in the organically reared meat-type birds. Those birds also demonstrated greater natural drip loss in thigh compared to meat of birds kept in a closed system. There was no evidence that access to open runs, enabled for slow-growing chickens, could alter dissection results and meat quality parameters. Variability in meat traits resulted mainly from various genotypes of chickens, their age, and the interaction between these two factors (Batkowska et al., 2014). Also, Shahin and Elazeem (2005) stated that the effect of diet (high or low content of protein and fibre) was essentially the same regardless of birds' breed (Hubbard and Anak broilers). However, Fanatico et al. (2009) confirmed statistically significant interaction of genotype and rearing system of birds in the case of such traits as carcass and wing yield, $\mathrm{pH}$ of breast muscle, and colour parameters of skin.

Berri (2000) reported that less intensive rearing conditions could constitute a significant factor determining meat quality if they concerned slow-growing birds. For the standard fastgrowing birds they did not influence any of the meat quality traits. Decreasing the energy level in feed may result in less tender and less succulent meat (more fibrous). Additionally, limited protein content could cause greater thermal drip loss.

In the current study the relations described by Allen et al. (1997) were confirmed. Analysing technological meat characteristics, those authors concluded that breast muscles of a darker colour indicated higher $\mathrm{pH}$ value, higher waterholding capacity, and natural and thermal water losses. These authors also found that the differences in technological parameters lasted regardless of the further way of meat processing, which could suggest that meat should be sorted according to the colour prior to further processing.

Lu et al. (2007) studied physico-chemical properties of the standard broiler-type chicken meat and the meat from a conservative chicken breed which had not been selected for growth rate. Birds were fed with complete balanced mixes. It was found that conventional broilers' muscles required significantly smaller shear force, which could indicate their greater tenderness compared to the second type of birds.

Results obtained from the newly created hybrid $(\mathrm{C} \times \mathrm{Sx}$ and $\mathrm{C} \times \mathrm{GP}$ ), such as final body weight (in the 12 th week of life), the amount of abdominal fat, proportions of carcasses' elements, and appropriate values of technological meat traits, point at the usefulness of these hybrids as a meat-type chicken under extensive housing conditions. Additionally, darker colour of breast and thigh meat of chickens, derived from a crossbreed of Cornish cocks and Sussex or Green-legged Partridgenous hens, can constitute an indicator for their carcasses' identification on the market.

Acknowledgements. Research was realised within the project "BIOŻYWNOŚĆ - innowacyjne, funkcjonalne produkty pochodzenia zwierzecego" (BIOFOOD - innovative, functional products of animal origin) no. POIG.01.01.02-014-090/09, co-financed by the European Union from the European Regional Development Fund within the Innovative Economy Operational Programme 2007-2013".

Edited by: K. Wimmers

Reviewed by: three anonymous referees 


\section{References}

Allen, C. D., Russell, S. M., and Fletcher, D. L.: The relationship of broiler breast meat color and $\mathrm{pH}$ to shelf-life and odor development, Poult. Sci., 76, 1042-1046, 1997.

Batkowska, J., Brodacki, A., Knaga, S., and Florek, M.: Slaughter traits and skin colour of newly crossed chicken broilers dedicated for extensive rearing system as a criterion of product identification and meat quality, Acta Agr. Scand. A, 64, 161-169, 2014.

Berri, C.: Variability of sensory and processing qualities of poultry meat, Worlds Poult. Sci., 56, 209-224, 2000.

Berri, C., Le Bihan-Duval, E., Baéza, E., Chartrin, P., Picgirard, L., Jehl, N., Quentin, M., Picard, M., and Duclos, M. J.: Further processing characteristics of breast and leg meat from fast-, medium- and slow-growing commercial chickens, Anim. Res., 54, 123-134, 2005.

Bizeray, D., Estevez, I., Leterrier, C., and Faure, J. M.: Influence of increased environmental complexity on leg condition, performance, and level of fearfulness in broilers, Poult. Sci., 81, 767773, 2002.

Castellini, C., Dal Bosco, A., Mugnai, C., and Bernardini, M.: Performance and behaviour of chickens with different growing rate reared according to the organic system, Ital. J. Anim. Sci., 1, 291-300, 2002.

Castellini, C., Berri, C., Le Bihan-Duval, E., and Martino, G.: Qualitative attributes and consumer perception of organic and freerange poultry meat, Worlds Poult. Sci., 64, 500-513, 2008.

CIE: International Commission and Illumination, Recommendation on Uniforms Colour Spaces, Colour Different Equation, Psychometric Colour Terms, Bureal Central de la CIE, Paris, 1978.

Dou, T. C., Shi, S. R., Sun, H. J., and Wang, K. H.: Growth rate, carcass traits and meat quality of slow-growing chicken grown according to three raising systems, Anim. Sci. Pap. Rep., 27, 361-369, 2009.

Fanatico, A. C., Cavitt, L. C., Pillai, P. B., Emmert, J. L., and Owens, C. M.: Evaluation of slower-growing broiler genotypes grown with and without outdoor access: Meat quality, Poult. Sci., 84, 1785-1790, 2005.

Fanatico, A. C., Pillai, P. B., Cavitt, L. C., Emmert, J. L., Meullenet, J. F., and Owens, C. M.: Evaluation of slower-growing broiler genotypes grown with and without outdoor access: Sensory attributes, Poultry Sci., 85, 337-343, 2006.

Fanatico, A. C., Pillai, P. B., Emmert, J. L., Gbur, E. E., Meullenet, J. F., and Owens, C. M.: Sensory attributes of slow- and fastgrowing chicken genotypes raised indoors or with outdoor access, Poultry Sci., 86, 2441-2449, 2007.

Fanatico, A. C., Pillai, P. B., Hester, P. Y., Falcone, C., Mench, J. A., Owens, C. M., and Emmert, J. L.: Performance, livability, and carcass yield of slow- and fast-growing chicken genotypes fed low-nutrient or standard diets and raised indoors or with outdoor access, Poultry Sci., 87, 1012-1021, 2008.
Fanatico, A. C., Owens, C. M., and Emmert, J. L.: Organic poultry production in the United States: Broilers, J. Appl. Poultry Res., 18, 355-366, 2009.

Gondwe, T. N. and Wollny, C. B. A.: Evaluation of the growth potential of local chickens in Malawi, Inter. J. Poult. Sci., 4, 64-70, 2005.

Grau, R. and Hamm, R.: Eine einfache Methode zur Bestimmung der Wasserbindung im Muskel, Naturwissenschaften, 40, 29-30, 1953 (in German).

Hahn, G. and Spindler, M.: Method of dissection of turkey carcases, Worlds Poultry Sci. J., 58, 179-197, 2002.

IBM: IBM SPSS Statistics for Windows, Version 20.0 Armonk, NY, 2011.

Lu, Q. Wen, J., and Zhang, H.: Effect of chronic heat exposure on fat deposition and meat quality in two genetic types of chicken, Poultry Sci., 86, 1059-1064, 2007.

Lundstrom, K. and Malmfors, G.: Variation in Light-Scattering and Water-Holding Capacity Along the Porcine Longissimus-Dorsi Muscle, Meat Sci., 15, 203-214, 1985.

Mikulski, D., Celej, J., Jankowski, J., Majewska, T., and Mikulska, M.: Growth Performance, Carcass Traits and Meat Quality of Slower-growing and Fast-growing Chickens Raised with and without Outdoor Access, Asian Austral. J. Anim., 24, 14071416, 2011.

Polish norm: PN-ISO 2917:2001, Oznaczenie pH [pH measurement], 2001 (in Polish).

Poltowicz, K. and Doktor, J.: Effect of free-range raising on performance, carcass attributes and meat quality of broiler chickens, Anim. Sci. Pap. Rep., 29, 139-149, 2011.

Rizzi, C., Marangon, A., and Chiericato, G. M.: Effect of genotype on slaughtering performance and meat physical and sensory characteristics of organic laying hens, Poultry Sci., 86, 128-135, 2007.

Santé, V. S., Lebert, A., LePottier, G., and Ouali, A.: Comparison between two statistical models for prediction of turkey breast meat colour, Meat Sci., 43, 283-290, 1996.

Shahin, K. A. and Elazeem, F. A.: Effects of breed, sex and diet and their interactions on carcass composition and tissue weight distribution of broiler chickens, Arch. Tierzucht, 48, 612-626, 2005.

Sogut, B., Inci, H., and Sengul, T.: Growth Performance and Carcass Traits of Broiler Reared in Conventional and Organic Conditions, Asian J. Anim. Vet. Adv., 6, 992-1000, 2011.

Souza, X. R., Faria, P. B., and Bressan, M. C.: Proximate Composition and Meat Quality of Broilers Reared under Different Production Systems, Braz. J. Poultry Sci., 13, 15-20, 2011.

Sundrum, A.: Organic livestock farming - A critical review, Livest. Prod. Sci., 67, 207-215, 2001. 